\title{
Organization of international carriage of goods
}

\section{by Transport}

\author{
Vsevolod Prykhodko $^{1}$, Ihor Vikovych ${ }^{2}$ \\ 1. Transport technology, Lviv Polytechnic National University, Ukraine, Lviv, Stepan Bandera street, 32, E-mail: \\ satrapandfeller@gmail.com \\ 2. Transport technology, Lviv Polytechnic National University, Ukraine, Lviv, Stepan Bandera street, 32, E-mail: \\ wikovigor@gmail.com
}

Abstract - The main factors affecting the organization of international road transport, the formation of the tariff on road freight transport in international traffic, the main international transport organizations in the field of motor transport, road transport, planning principles of international freight traffic are considered. The conducted work will allow to estimate the degree of factors, which influence on the quality of international transport services of Ukraine.

Keywords - international automobile transportation, principles of cargo transportation planning, international transport tariff, freight road transportation, cost of transportation.

\section{Introduction}

Location of Ukraine allows it to be a good bridge for transit transportation of cargoes and passengers between the states of Europe, Asia and the Middle East. Proceeding from this, the transport system is one of the components of success and indispensable attributes of our state to which high demands should be made regarding the quality, regularity and reliability of transport links, the storage of goods and safety of transportation of passengers, terms and cost of delivery, etc. The position of Ukraine as a transit state is one of the most attractive components of the Ukrainian market for foreign investors and manufacturers, since Western European countries can not ignore such a large (in size and population) is a country located at the crossroads of trade roads.

\section{Analysis of previous studies and publications}

The question of organization of international transport transportations always have had an important value, which was expressed by Ukrainian and foreign specialists in their scientific works and researches, such as N.V. Ivasyshina [1], O.I. Kiryan [2], E.V. Kryshavskyi [3], I. B. Shevchenko [4], D. Parahomchuk, A. E. Gorev.

\section{Formulation of the problem}

The main goal of the work is to organize the key factors for the formation of road freight transport at the international level, determine their impact on the Ukrainian economy, introduce solutions to transport problems and improve the international road transport system.

\section{Main material}

International road transport is a traditional type of transportation regulated by the international agreements. The study relevance of legal problems associated with this type of transportation are caused by e political-economic, geostrategic and theoretical factors. International trucking has an advantage over a rail and sea transportation by its urgency and regularity of cargo delivery, conducting directly to the places of destinations.

Interstate regulation of international transport is ensured by the bilateral and multilateral agreements. In connection with the expansion of international trade, multilateral treaties are 
becoming increasingly important for the implementation. What's why, a lot of international organizations are created. It includes an regulation, organization and development of rules and regulations for the implementation of international road transport (IRT). The main normative documents in the field of controlling in international road transport are being prepared within the framework of the UNECE, which is based in Geneva, EU legislative acts are divided into relevant groups. IRU's activities in the field of valuation are aimed, first of all, at the formation of agreements and uniform documents in order to simplify customs formalities and thus accelerate the delivery of goods.

Program of the International CMR Consignment Note, which is implemented in 60 countries.

The International Federation of Freight Forwarders Associations (FIATA). It was founded in Vienna (Austria) on May 31, 1926 as a professional Freight Forwarders Association to ensure the protection of the interests of freight forwarders on the international level.

Automobile transport as the most efficient type of transport for the conveyance of bulk cargoes. This kind of transport begins and ends with transport in the sea, river and railway transport. Motor transport ensures the functioning and territorial organization of all branches of the national economy, occupies an important place in the economy of Ukraine.

The length of the roads is shown in 10 countries with the largest highways in the world in the Table 1:

Table 1

The length of the roads in 10 countries with the largest highways in the world

\begin{tabular}{|c|c|c|}
\hline № & Country & Length of roads, mil. km \\
\hline 1 & The USA & 6,5 \\
\hline 2 & India & 4,6 \\
\hline 3 & China & 4,1 \\
\hline 4 & Brazil & 1,5 \\
\hline 5 & Russia & 1,2 \\
\hline 6 & Japan & 1,2 \\
\hline 7 & Canada & 1,0 \\
\hline 8 & France & 1,0 \\
\hline 9 & Australia & 0,8 \\
\hline 10 & South Africa & 0,7 \\
\hline
\end{tabular}

The main highways of Ukraine are presented in Figure 1.

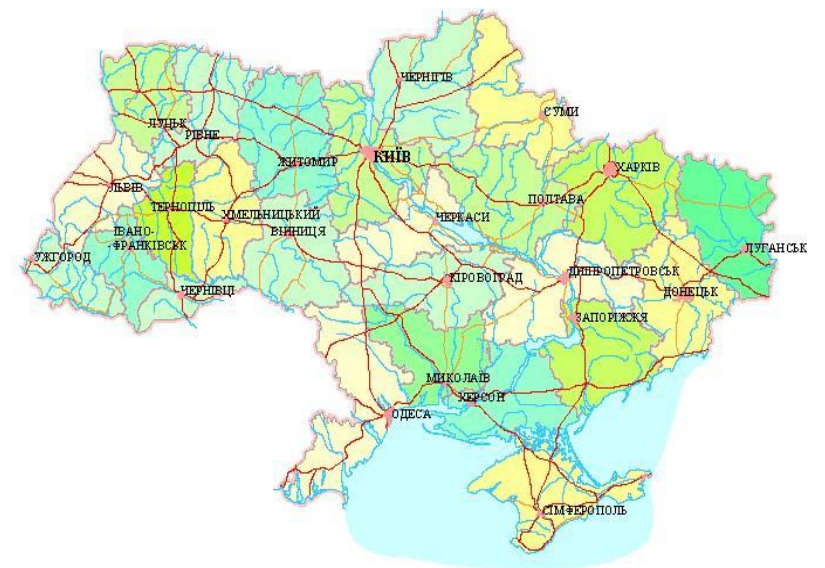

Figure 1. The network of highways of Ukraine 
The most important highways of Ukraine are: Odessa - Kiev - Chernihiv, Kharkiv Donbass, Dnipropetrovsk - Zaporozhye, Zaporozhye - Sevastopol, Lviv - Kiev, Kharkiv - Kiev, Poltava - Chisinau presented in Figure 2:

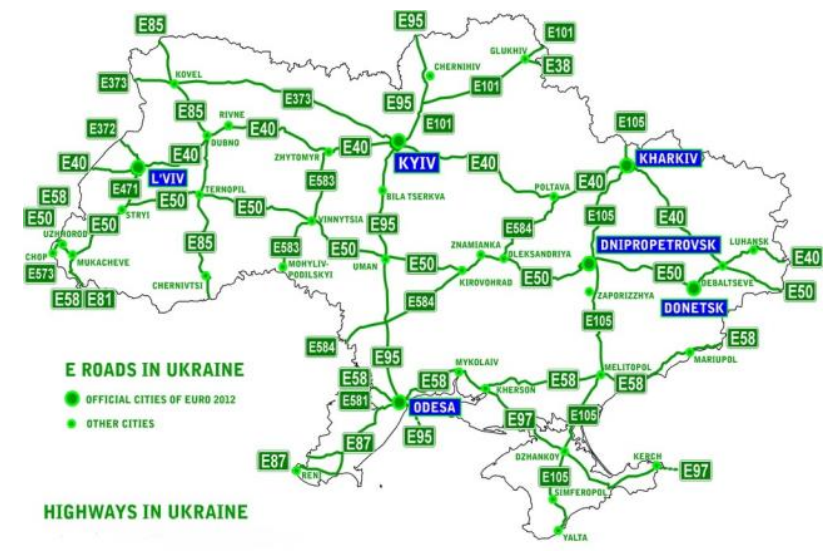

Figure 2. The most important highways of Ukraine

The following international transport corridors pass through Ukraine's territory:

1. Pan-European \#3: From Germany to Ukraine through Poland (Berlin/Dresden Wroclaw/Katowice/Przemysl - Mostyska/Lviv/Kiev)

2. Pan-European \#5: From Italy to Ukraine, including such countries as: Slovakia, Slovenia, Hungary, Bosnia and Herzegovina, Croatia.

3. Pan-European \#7 Danube (aqueous): From Austria to Moldova including such countries as: Slovakia, Hungary, Croatia, Yugoslavia, Romania, Bulgaria.

4. Pan-European \#9: From - to: Finland - Greece; Poland and Litva - Greece; Russia Greece, including such countries as: Spain, Belarus, Ukraine, Moldova, Romania, Bulgaria.

The international transport corridors, that cross Ukraine, are converging in the largest transport hubs - Lviv, Kyiv and Odesa. The transport corridor \#3 passes through the city of Lviv, and also the corridor \#5 ends; Through the city passes the corridor \#9 and ends corridor \#3; In the city of Odessa, the corridor \#9 is connected to the Euro-Asian transport corridor (it is currently recognized by three countries: Ukraine, Azerbaijan, Georgia).

An analysis of the location of the regional centers of Ukraine on the main highways on the international transport corridors shows that:

1) Odessa has the best location on the main highways: there are three international highways in this large transport hub (Corridor \#9, the Baltic Sea-Black Sea and the CHEC corridor) converge;

2) Corridor \# 9 with branch in Minsk and \# 3 converge in Kyiv;

3) the corridors \#3 and \#5 coincide in Lviv, and corridor \#5 passes through Uzhhorod;

4) Apart from this, on the important mainline of the BSEC are Donetsk, Dnipropetrovsk, Odessa (as well as the Danube ports of Reni and Izmail).

It should be noted that there are negative aspects of the passage of transport corridors through the territory of Ukraine for the development of regions. Firstly, the development of corridors takes place on the Right Bank of Ukraine, as well as in the Maritime Regions (Donetsk, Zaporozhye, Mykolayiv, and Odesa), with the Left Bank Ukraine (in particular, Kharkiv, Poltava, and Sumy Oblasts) being ignored by these projects. Secondly, important transport hubs 
such as Kharkiv, Chernihiv, Lugansk and others, which play an important role for domestic transportation, remain out of sight.

The most important motorways of Ukraine are: Kiev-Poltava-Kharkiv-Rostov-on-Don, Kiev-Moscow, Kiev-St.-Petersburg, Kiev-Odessa, Moscow-Kharkiv-Zaporizhzhia-Simferopol, Kiev-Zhytomyr-Rivne-Lviv-Uzhgorod, Kiev-Dnepropetrovsk-Donetsk-Mariupol and others. About a third of hard-coated roads in Ukraine have a capital type of coverage, mainly on roads of national and intergovernmental importance. In this case, the transition type of coating (gravel, highway, asphalted, pavement) predominates.

Principles of international cargo transportation planning: Planning freight transportation is divided into perspective, current and operational.

Perspective (strategic) planning involves the development of key areas and performance indicators for a long period of 5 to 15 years. In this framework, all calculations are carried out on the forecasting basis of the development of economic and social processes in the region and analysis of market conditions. During forward planning, the use of modern forecasting methods has a great importance.

Expected volumes of transportations of industrial cargoes are determined in relation to volumes of the existing transportations and the expected development of industry according to Eq. 1:

$$
Q_{\Pi}=Q_{\mathrm{C}} K_{n} K_{\Pi}
$$

where $Q_{\Pi}$ - is the estimated volume of goods, transported by road, thousand tons; $Q_{\mathrm{C}}$ - is an actual volume of goods, transported by road during the current period, thousand tons; $K_{n}$ - is a coefficient of change of volume of industrial goods for the forecasted period; $K_{\Pi^{-}}$- is a coefficient of transportation repetition of industrial goods, $K_{I}=1,05 . .1,2$

$$
K_{I}=\frac{K_{c h} V_{I I}}{V_{c}}
$$

where $K_{c n}$ - is the coefficient, which takes into account the reduction of material production of industrial production and the volumes reduction of road transport, comprising to 1 million years of gross industrial output, estimated $K_{c H}=0,95 . .0,98 ; V_{\Pi}$ - is a gross production of industry for the forecasted period, million years.; $V_{c}$ - gross output of industry for the current period, million years.

While planning the transportation capabilities of the MTC is conducted (Eq. 3):

$$
Q=Д_{K} \alpha_{B} \sum\left(A_{C I} U_{P . Д}\right)_{i}
$$

where the index " $i$ " refers to the search of the warehouse stock of the MTC fleet on models that perform a certain daily task.

The output factor $\alpha_{B}$, given the stability of the organization of work, is mainly influenced by the downtime of vehicle during maintenance and repair. It should be borne in mind that after $4 . .5$ years of operation vehicle these simple ones sharply increase, resulting in a corresponding decrease $\alpha_{B}$.

The volume of goods transported for change, $U_{P . Д}$ in addition to other factors, depends on road conditions, technical speed of vehicle on the line, reliability of MTC. The technical speed of 
the vehicle with the service life are reduced both due to the deterioration of traction dynamic qualities, and due to an increase in downtime on the line in order to eliminate minor malfunctions. Some technical and operational indicators of the MTC depend on road conditions and service life.

The cost of road freight transport involves taking into account the main influencing factors on cost, which include: distance of transportation; weight of cargo; the volume of cargo; type and capacity of the car; time of transportation; the area in which the transportation is carried out.

These factors form the basis of the transport tariff, since they depend on fuel consumption and depreciation of the motor vehicle. In the case of an increase in the distance of transportation, the cost of transport services will increase. Today, the tariff rate for international traffic is $0.8-1.2$ euros / $\mathrm{km}$ for trucks and 0.45-0.6 euros / $\mathrm{km}$ for cars with a capacity of up to 1 ton. However, an regularity is traced, due to which, an increase in the distance of transportation, the tariff rate for 1 $\mathrm{km}$ run decreases. This is due to such a factor as the time of transportation. International freight traffic takes into account the time not only for the direct movement of goods, but also for loading / unloading, receipt and verification of shipment and crossing of the border. In the case of multiple points of loading or unloading, an additional fee will be 30-50 euros for each point. The value of the freight may also increase if the place of customs clearance and customs does not coincide with the points of loading and unloading. Graphically, the dependence of transport costs on the distance of transportation can be represented as a curve of transport costs (Figure 3).

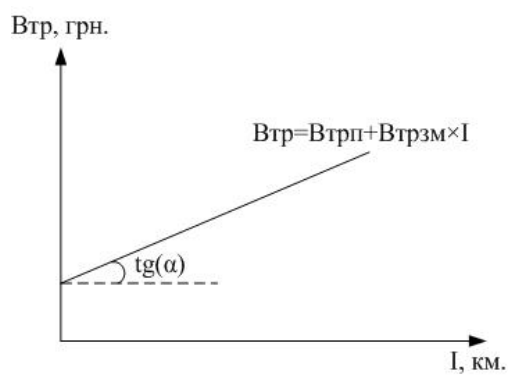

Figure 3. Graphic interpretation of the dependence of transport costs on the distance and time of transportation

Considering that the main item of expenditure in road transport is the cost of fuel, then factors like mass and volume of cargo should also be taken into account. At one and the same distance of transportation fuel costs will vary depending on the weight of the load. In the case of a larger mass, the specific transport costs will be higher and vice versa. Separately, the impact on transportation of cargoes by motor transport should be highlighted by a significant increase in fuel and lubricants, raising the level of minimum wages and a significant increase in the cost of other material resources that affect the formation of the cost of transportation.

In addition to physical factors, the amount of fuel costs depends on the country where the transportation takes place.

The basic model of transport costs for international road transport is Eq. 4:

$$
B_{m p}=C \cdot P_{6 n} \cdot k_{P} \cdot V \cdot k_{\mathrm{v}} \cdot T \cdot k_{T} \cdot t \cdot k
$$

where $\mathrm{C}$ - transport tariff, UAH / t $\cdot \mathrm{km} ; P_{6 n}$ - lifting capacity of the vehicle, ton; $k_{P}$ - coefficient of lifting capacity usage; $\mathrm{V}$ - technical speed, $\mathrm{km} / \mathrm{h} ; k_{\mathrm{v}}$ - coefficient of useful use of the run; $\mathrm{T}$ - calendar period, days; $k_{T}$ - usage factor of calendar time; $\mathrm{t}$ - daily fund time, year.; $\mathrm{k}$ - daily utilization rate. 
Tariffs for road freight transport, instead of transportation, conducted by other types of transport, are characterized by flexibility and mobility. In addition to the cost factor, a significant impact on the size of the tariff may have a level of competition in the market. The cost of transportation often takes into account the ratio of demand and supply for transport services. The tariff rate depends on the size of competition in each separate segment of the market.

Operational planning is a specification of scheduled tasks in terms of execution time, in space (in terms of execution of production tasks), on the specifics of technology and the organization of production of a controlled object. Operational planning involves the development of work plans in general for MTC and specific MTC and drivers for a month, a week and a change. In the process of operational planning, the following tasks are addressed: calculation of transportation capabilities of the MTC; calculation of optimal traffic routes; on drawing up of hourly schedules of work of vehicle; about drawing up a plan of work on the clientele; calculation of estimated costs and necessary resources for transportation; preparation of a fieryday work plan of the MTC, timetable for issuing vehicle on the line and documentation.

The main operational planning document is a variable-day plan:

In case of hourly use of vehicle in a variable-day plan, the time of delivery and the duration of the work of the MTC on the customer according to the marks of vehicles is reflected.

On the one hand, the variable-daily plan is compiled on the basis of the data on the transportation needs, which consist of the final MTC contracts, received on one-time applications for carriage. On the other side, the estimated capabilities of the MTC are based on data on a reliable and ready-to-operate drivers.

The main problems of international road transport include: pollution of the environment; accident rate; high costs; unsatisfactory condition of the road complex; technical condition of cars; low qualification of drivers.

Problems of international transport are solved in various international transport organizations. The work of the Inland Transport Committee of the United Nations Economic Commission for Europe, the European Conference of Transport Ministers, the International Road Transport Union, the International Federation of Forwarding Associations, the Coordinating Transport Meeting of Ministers of Transport of the CIS countries is of great importance for the development of international road transport.

Ways of solving problems and improving the system of international road transport are: improvement of the system of management and control of international transportation; the use of a rigid licensing system; ensuring quality market access conditions; creation of a single integrated management system for road transport safety; state financing; attraction of funds of insurance organizations; availability of skilled personnel; application of rational methods of transportation.

Various intergovernmental organizations, as well as individual states, must unify the rules governing international transport by road. Therefore, for a deeper concentration of international norms governing relations in the field of international transport by road, it is necessary to accelerate the process of creating universal international norms.

Ukraine, planning to enter the general European transport network, should adopt the principles of the European common transport policy, adapting them to Ukrainian conditions. The main purpose of this policy is to create a single market for transport services, to improve the efficiency of transport enterprises and transport infrastructure, to increase the safety of transportation, to ensure the reliability and comfort of passenger travel and cargo transportation. 


\section{Conclusions}

Comprehensive study of the current state of international transport has allowed to identify a number of factors that significantly affect the efficiency of transport services in international traffic, as well as formulate solutions to existing problems in this area.

The researched problems of motor transport, arising in the conditions of aggravation of the economic situation in the country, are considered in time of reforming the transport sector of the economy. Taking into account that the unified systems of transport tariffs are used in the European countries, the foundation is based on differentiation, depending on the distance of transportation, the type of cargo, the volume of shipment, which ensures the same working conditions for carriers, Ukrainian carriers need to try to take into account more comprehensively the interests of the main participants of transport transportation. Under such conditions, Ukrainian carriers will be able to compete significantly with European transport companies and become a full-fledged participant in the international transport process. Increasing investment in the industry, improving tariff policies, developing international transportation, implementing road construction projects under concession conditions, building and repairing roads, and implementing market reform. All above mentioned will contribute to the efficient development of the automotive industry.

\section{References}

[1] Ivasyshina N.V. Improving the efficiency of international road transport of goods [Text]: author's abstract. / Ialyushina Natalya Volodymyrivna; National Transport University. - K., 2002. - $21 \mathrm{p}$.

[2] Kirian OI General characteristics of the domestic competitive market of transport services / O.I.Kiryan // Bulletin of the National Technical University. Sir: Technical progress and production efficiency. - 2014. -№ 33. - P. 3-13.

[3] E. B. Krikavysky. Logistic management: textbook / E. B. Krikavysky. - Lviv: Vat. Lviv Polytechnic University, 2005. - 684 pp

[4] Shevchenko I.V. Cost of freight transportation in the formation of tariffs in international traffic / I.V. Shevchenko // Bulletin of Dnipropetrovsk National University of Railway Transport. Sir: Science and progress in transport. - 2009. - No. 28 - P. 291-301.

[5] Kozina K.G. Theoretical and methodical bases of factor analysis of competitiveness of international road freight transport of Ukraine / K. G. Kozina // Scientific Bulletin of the Kherson State University. Sir: Economic Sciences. -2014. - №6. Ch. 2. - P. 203-206. 